Gulawentah: Jurnal Studi Sosial

ISSN 2528-6293 (Print); ISSN 2528-6871 (Online)

Vol. 5, No. 1, Juni 2020, Hal 1-16

Tersedia online: http://e-journal.unipma.ac.id/index.php/gulawentah

\title{
Nilai Budaya Ritual Perang Topat Sebagai Sumber Pembelajaran IPS Berbasis Kearifan Lokal di Sekolah Dasar
}

\author{
Arif Widodo \\ Program Studi Pendidikan Guru Sekolah Dasar, Fakultas Keguruan dan Ilmu Pendidikan \\ Universitas Mataram, Jl. Majapahit No. 62 Mataram NTB, Indonesia \\ Email: arifwidodo@unram.ac.id
}

Naskah diterima: 30/4/2020; Revisi: 19/5/2020; Disetujui: 27/5/2020

\begin{abstract}
Abstrak
Lombok Barat memiliki keragaman budaya yang sangat tinggi. Berbagai macam suku, agama dan budaya hidup berdampingan di Lombok Barat. Salah satu bentuk budaya yang terus dilestarikan oleh masyarakat Lombok Barat adalah ritual Perang Topat. Penelitian ini bertujuan untuk menganalisis nilai-nilai budaya ritual Perang Topat sebagai sumber pembelajaran IPS di sekolah dasar. Penelitian ini didesain dalam bentuk penelitian kualitatif dengan pendekatan etnometodologi. Pendekatan etnometodologi digunakan untuk menggali, menjelaskan memahami, dan menguraikan nilai-nilai budaya yang terdapat pada ritual Perang Topat. Tahapan dalam penelitian ini antara lain: pengumpulan data, reduksi data, penyajian data, dan penarikan kesimpulan. Pengumpulan data melalui observasi dan studi kepustakaan. Analisis data menggunakan model analisis tema Spradley. Analisis dilakukan bersama-sama dengan pengumpulan data. Tahapan analisisnya adalah analisis domein, analisis taksonomi, analisis komponensial, dan analisis tema kultural. Permasalahan utama yang dikaji dalam penelitian ini antara lain: nilai-nilai apa saja yang terdapat pada ritual Perang Topat? Apakah nilai budaya ritual Perang Topat relevan dengan KI/KD atau tema pembelajaran IPS di sekolah dasar? apa saja topik pembelajaran yang relevan dengan nilai budaya ritual Perang Topat? Hasil penelitian menunjukkan nilai-nilai budaya yang terkandung dalam ritual Perang Topat antara lain: nilai kompromi, nilai religius, nilai historis, nilai kebersamaan dan persamaan derajat, nilai gotong royong, nilai musyawarah dan kekeluargaan, serta nilai toleransi. Nilai-nilai budaya dalam ritual tersebut relevan dengan topik pembelajaran IPS di kelas IV dan VI. Topik pembelajaran yang relevan dengan nilai budaya ritual Perang Topat antara lain tema 1 "indahnya kebersamaan", tema 7 "indahnya keragaman di Negeriku" dan tema 8 "daerah tempat tinggalku" yang terdapat di kelas IV serta tema 2 "persatuan dalam perbedaan" di kelas VI.
\end{abstract}

Kata kunci: ritual perang topat; sumber belajar; IPS SD

\section{Cultural Value of Topat War Rituals as a Source of Social Wisdom Learning Based on Local Wisdom in Primary Schools}

\begin{abstract}
West Lombok has very high cultural diversity. Various tribes, religions, and cultures co-exist in West Lombok. One form of culture that continues to be preserved by the people of West Lombok is the Topat War ritual. This study aims to analyze the cultural values of Topat War rituals as a source of social studies learning in elementary schools. This research was designed in the form of qualitative research with an ethnomethodology approach. The Ethnomethodology approach
\end{abstract}

DOI: $10.25273 /$ gulawentah.v5i1.6359

Some rights reserved. 
is used to explore, understand, explain, and describe the cultural values contained in the Topat War ritual. The stages in this research include data collection, data reduction, data presentation, and concluding. Data collection through observation and study of literature. Data analysis uses the Spradley theme analysis model. The analysis was carried out together with data collection. The stages of the analysis are domain analysis, taxonomic analysis, componential analysis, and cultural theme analysis. The main problems examined in this study include: what values are found in the rituals of the Topat War? Is the cultural value of Topat War rituals relevant to KI / KD or the theme of social studies learning in elementary schools? what are the learning topics that are relevant to the cultural value of the Topat War rituals? The results showed the cultural values contained in the ritual of the Topat War, among others: compromise value, religious value, historical value, togetherness and degree of equality, cooperation value, the value of deliberation and kinship, and tolerance value. The cultural values in the ritual are relevant to the topic of social studies learning in grades IV and VI. Learning topics that are relevant to the cultural values of the Topat War rituals include theme 1 "the beauty of togetherness", theme 7 "the beauty of diversity in my country" and theme 8 "the area where I live" contained in class IV and theme 2 "unity in differences" in class VI.

Keywords: topat war ritual; learning resources; elementary school social studies

\section{Pendahuluan}

Pendidikan IPS merupakan salah satu mata pelajaran wajib di sekolah mulai dari sekolah dasar hingga sekolah menengah sesuai dengan amanah Undang-undang Sisdiknas tahun 2003. Pendidikan IPS menurut (Sapriya, 2017) merupakan integrasi dari berbagai macam ilmu sosial, ilmu pengetahuan alam dan humaniora yang telah dikemas melalui metode ilmiah dan pedagogis sesuai dengan kepentingan pembelajaran di sekolah. Tujuan dari pembelajaran IPS di sekolah adalah mempersiapkan perserta didik menjadi warga Negara yang baik serta mampu menguasai pengetahuan, sikap dan nilai yang berguna dalam menyelesaikan masalah pribadi maupun masalah sosial. Melalui pembelajaran IPS di sekolah peserta didik dilatih agar dapat memiliki kemampuan untuk berpartisipasi aktif dalam bidang sosial, memiliki kepekaan sosial dan kepedulian sosial yang tinggi. Melalui keterampilan tersebut peserta didik diharapkan dapat memiliki sikap dan mental yang positif terhadap berbagai ketimpangan sosial yang terjadi di dalam lingkungan sosial. Terlebih lagi tantangan hidup di masa depan lebih berat dan banyak masalah-masalah baru timbul akibat perubahan zaman. Dibutuhkan keterampilan yang berpikir tingkat tinggi dalam menghadapi berbagai permasalahan, salah satunya dengan belajar berpikir kritis (Widodo, Indraswati, \& Sobri, 2019). Hal ini sesuai dengan tujuan pendidikan IPS itu sendiri yaitu memberi bekal agar peserta didik mampu berpikir kritis, rasa ingin tahu, inkuiri, terampil memecahkan masalah, terampil mengolah informasi dan berperan aktif dalam kehidupan sosial.

Pembelajaran IPS di sekolah dasar menurut Susanto (2014) perlu dilakukan pembaharuan. Model pembalajaran yang diterapkan saat ini masih bersifat konvensional. Pembelajaran lebih sering menggunakan metode ceramah. Buku teks adalah satu-satunya sumber belajar yang wajib dikuasai siswa. Pembelajaran dengan metode ceramah membuat siswa kurang terlibat dalam kegiatan pembelajaran (Tumini, 2019). Pembelajaran model konvensional lebih banyak mengandalkan ingatan dan hafalan sehingga peserta didik tidak dapat mengambil makna dari apa yang telah dipelajari. Permasalahan hidup di abad 21 tidak cukup dengan kemampuan menghafal saja tetapi lebih menekankan pada kompetensi sosial yang berkaitan dengan aspek kolaborasi dan kemampuan berpikir tingkat tinggi (Widodo, Indraswati, Radiusman, et al., 2019). Hal ini sesuai dengan pendapat Gunawan (2016) bahwa salah satu tujuan dari mata pelajaran IPS di sekolah dasar adalah agar peserta didik mampu bekerjasama, berkomunikasi dan berkompetisi dalam kemajemukan masyarakat baik tingkat lokal, regional, maupun internasional. 
Model pembelajaran dapat dikatakan modern menurut Susanto (2014) jika model pembelajaran tersebut telah sesuai dengan perkembangan zaman, salah satunya indikatornya adalah telah memperhatikan lingkungan sekitar di mana perserta didik berada. Model pembelajaran IPS yang direkomendasikan adalah pembelajaran kontekstual. Salah satu ciri pembelajaran kontekstual adalah pemeliharaan dan pemanfaatan lingkungan sekitar sebagai sumber belajar. Melalui pembelajaran kontekstual peserta didik dapat memahami permasalahan secara konkrit dan dapat belajar secara nyata dalam kehidupan bermasyarakat. Peserta didik dapat belajar langsung terkait dengan nilai sosial dan nilai budaya dari lingkungan di mana mereka belajar. Salah satu contoh kompetensi inti (KI) dan kompetensi dasar (KD) IPS yang berkaitan erat dengan aspek budaya dapat ditemui di kelas IV SD yaitu pada KI3 dan KI4. KI3 menyangkut aspek kognitif yang berkaitan dengan aspek pengetahuan, sedangkan KI 4 berkaitan dengan aspek psikomotorik yang berhubungan dengan keterampilan dan perilaku. Kompetensi dasar yang harus dicapai oleh siswa di kelas IV salah satunya adalah memahami kehidupan manusia dalam aspek sosial, ekonomi, pendidikan dan budaya di masyarakat sekitar. Kompetensi tersebut terdapat pada KD 3.4. Pada ranah keterampilan siswa diharapkan mampu menggambarkan kehidupan sosial, ekonomi, dan budaya yang ada di lingkungan masyarakat. Kompetensi dasar ini jika mengacu pada kurikulum 2013 revisi dapat dikaitkan dengan tema 7 yaitu "indahnya keragaman di Negeriku". Tema 7 dipecah menjadi beberapa subtema yang tersebar dalam beberapa kegiatan pembelajaran. Subtema yang terdapat dalam tema 7 antara lain "keragaman suku bangsa dan agama di negeriku", "indahnya keragaman budaya di negeriku", dan "indahnya persatuan dan kesatuan negeriku".

Tema pembelajaran 7 "indahnya keragaman di Negeriku" di kelas IV memiliki hubungan yang sangat erat dengan aspek kebudayaan. Permasalahannya adalah siswa di seluruh Indonesia dipaksa belajar pada materi yang sama sesuai dengan buku siswa, termasuk juga siswa yang berdomisili di wilayah Lombok Barat. Tidak banyak guru yang mampu menggali potensi budaya lokal untuk dijadikan sumber pembelajaran. Siswa dipaksa belajar mengenai budaya daerah lain sedangkan budaya daerahnya sendiri banyak terlewatkan. Salah satu contohnya adalah pada tema 7 subtema 2 buku tematik kurikulum 2013 siswa disajikan dengan kegiatan ayo membaca yang berjudul "Urang Kanekes, Si Suku Baduy" (Kusumawati, 2017). Bagi siswa yang sejak kecil berdomisili di wilayah Lombok dan sekitarnya akan terasa asing jika membaca bacaan tersebut. Pertanyaanya adalah apa manfaat mempelajari materi tersebut bagi anak Lombok? Jika hanya menambah pengetahuan maka tidak ada makna yang dapat diambil bagi kehidupan siswa di Lombok. Tidak ada kesan yang mendalam setelah mempelajari materi tersebut. Hal ini membuat pembelajaran IPS semakin abstrak dalam pemikiran siswa. Proses pembelajaran semacam ini bertolak belakang dengan model pembelajaran kontekstual yang menekankan pembelajaran dari permasalahan konkrit dan terdekat menuju permasalahan yang lebih jauh dan abstrak. Implikasinya adalah pelajaran IPS dianggap sulit karena harus menghafalkan konsep yang tidak pernah siswa mengerti sebelumnya. Pembelajaran akan lebih baik jika guru mampu menyuguhkan materi pembelajaran yang kontekstual sehingga bermakna bagi kehidupan siswa. Terlebih lagi potensi sumber belajar IPS yang berkaitan dengan aspek budaya sangat melimpah. Maka dari itu guru harus memiliki ketajaman analisis agar materi yang diajarkan memiliki manfaat bagi siswa.

Masing-masing daerah memiliki lingkungan sosial budaya yang berpotensi untuk dijadikan sumber belajar, salah satunya adalah daerah Lombok Barat. Daerah ini memiliki ragam tradisi kebudayaan yang unik mulai dari koleksi babad hingga ritual budaya. Salah satu ritual yang terkenal di daerah Lombok Barat adalah ritual Perang Topat. Ritual ini dilaksanakan satu tahun sekali oleh masyarakat Sasak Islam Wetu Telu dan suku Bali yang beragama Hindu. Lokasi Perang Topat adalah Pura Lingsar atau pura Gaduh yang terletak di daerah Lingsar kabupaten Lombok Barat. Pura Gaduh merupakan tempat suci bagi agama Hindu yang berfungsi sebagai tempat sembahyang sedangkan Kemaliq merupakan tempat yang disucikan atau dikeramatkan umat Islam di desa Lingsar (Sarpin \& Pramunarti, 2017). Pura Lingsar 
merupakan salah satu jenis pura Khayangan maka dari itu dapat digunakan untuk persembahyangan umum. Pura ini memiliki catatan sejarah yang panjang. Pada awalnya Pura Lingsar hanya satu yaitu pura Lingsar Gaduh, namun dengan pertimbangan agar dapat menampung umat yang banyak akhirnya pada masa Anak Agung Ngurah ditambah satu pura lagi yang diberi nama pura Lingsar Ulon. Kedua pura ini memiliki fungsi yang sama yaitu sebagai persembahyangan umum. Ritual Perang Topat dilaksanakan setahun sekali bertepatan dengan purnamaning sasih keenam masan ngaro yaitu disaat masyarakat Lombok yang berprofesi sebagai petani menanam padi di sawah. Masyarakat Lombok membagi satu tahun menjadi dua musim yaitu musim kemarau yang disebut masan balit dan musim penghujan yang disebut dengan masan ujan. Waktu menanam padi adalah saat musim penghujan, sehingga pelaksanaan ritual Perang Topat dilaksanakan pada musim hujan. Ritual keagamaan berhubungan dengan unsur magis sehingga dalam pelaksanaannya harus memperhatikan waktu dan tempat yang telah ditentukan. Jika dua hal ini dilanggar maka akan berdampak negatif, karena setiap ritual memiliki makna, tujuan dan nilai-nilai tertentu. Sebagian besar masyarakat Lombok Barat ikut serta dalam ritual ini dari anak-anak hingga dewasa. Melihat begitu antusiasnya partisipasi masyarakat dalam ritual tersebut maka peneliti tertarik untuk melakukan kajian terhadap ritual budaya tersebut. Tujuan utama dalam penelitian ini adalah mengkaji makna dan nilai-nilai budaya lokal yang terkandung dalam ritual perang Topat agar dapat digunakan sebagai sumber pembelajaran IPS di sekolah dasar berbasis kearifan lokal.

Kebudayaan merupakan segala aktivitas intelektual, spiritual, artistik, estetik, cara hidup, kepercayaan dan kebiasaan hidup yang dilakukan oleh seseorang maupun kelompok masyarakat tertentu (Sutrisno \& Putranto, 2005: 258). Berdasarkan pendapat tersebut dapat diketahui bahwa kebudayaan memiliki aspek yang sangat luas. Menurut pendapat (Bakker SJ, 1984: 28) merumuskan pengertian kebudayaan bukanlah perkara yang mudah. Setidaknya terdapat 23 ahli yang telah merumuskan pengertian kebudayaan. Namun demikian sebagian besar ahli sepakat bahwa setiap sistem budaya memiliki seperangkat nilai yang dijunjung tinggi oleh masyarakat pendukungya. Menurut Nugroho Notosusanto nilai budaya adalah inti dari sebuah kebudayaan karena dapat mempengaruhi setiap aspek kehidupan manusia (Rosyadi, Mintosih, \& Soeloso, 1995: 174). Menurut Koentjaraningrat nilai budaya diartikan sebagai konsep abstrak yang berkaitan dengan segala sesuatu yang dianggap penting dan bernilai dalam kehidupan manusia (Wiwik Pertiwi, Hartati, Pananrangi Hamid, 1998: 9). Nilai budaya disebarluaskan oleh masyarakat itu sendiri melalui proses sosialisasi baik menggunakan lisan maupun tulisan. Sehingga setiap kelompok masyarakat dapat memiliki dan membentuk kebudayaan sebagai hasil kesepakatan dalam proses sosial yang berlaku pada lokalitas tertentu. Menurut Mintosih, Lestarining, \& Herliswani (1999: 156) mengkaji nilai-nilai budaya lokal pada hakikatnya juga menunjang perkembangan kebudayaan nasional. Eksistensi sebuah bangsa tergantung pada eksistensi kebudayaan nasionalnya. Maka dari itu dengan mengkaji nilai-nilai budaya lokal berarti telah menjaga eksistensi bangsa itu sendiri. Hal ini dikarenakan puncak kebudayaan nasional merupakan akumulasi dan adaptasi dari berbagai macam nilai-nilai luhur budaya lokal kemudian diakui untuk membentuk kebudayaan nasional. Meskipun demikian nilai budaya memiliki keterbatasan. Tidak semua nilai budaya bersifat universal. Terdapat nilai-nilai budaya tertentu yang dianggap baik oleh sebuah kelompok tetapi belum tentu baik menurut kelompok yang lain. Maka dari itu setiap peserta didik perlu diberikan tentang pendidikan nilai terutama mengenali nilai-nilai budaya yang terdapat pada lingkungannya masing-masing sebelum belajar tentang nilai budaya suku lain. Terlebih lagi pendidikan IPS merupakan salah satu mata pelajaran yang memiliki kedekatan dengan aspek kebudayaan seharusnya dapat memfasilitasi pembelajaran nilai terhadap peserta didik. Maka dari itu pembelajaran IPS dengan menggunakan pendekatan kearifan lokal sudah saatnya diterapkan agar siswa di daerah tidak tercabut dari akar budayanya sendiri. Salah satu caranya adalah memanfaatkan lingkungan budaya masyarakat setempat sebagai sumber belajar. 
Sumber belajar bagi seorang guru memiliki peran yang sangat penting dalam penyusunan bahan ajar. Menurut Prastowo (2015) potensi sumber belajar yang dapat ditemui sangat banyak dan melimpah, tergantung kreativitas dan kejelian seorang guru dalam memanfaatkan sumber belajar. Ironisnya masih banyak terdapat guru IPS yang merasa kesulitan dalam mencari sumber belajar. Banyak diantara guru yang beranggapan bahwa sumber belajar itu harus dicari di tempat yang jauh dan membutuhkan dana yang banyak. Hal ini dikarenakan tidak banyak guru yang memahami tentang hakikat dari sumber belajar itu sendiri. Sumber belajar merupakan segala sesuatu yang dapat menimbulkan proses belajar. Berdasarkan pengertian tersebut dapat dipahami bahwa sumber belajar itu tidak hanya buku teks dan LKS, tetapi masih banyak lagi lainnya. Salah satu hal yang dapat dimanfaatkan sebagai sumber belajar adalah lingkugan. Lingkungan dalam hal ini dapat berupa lingkungan sosial, alam sekitar maupun lingkungan budaya. Keterbatasan guru dalam melakukan kreasi terhadap sumber belajar mengakibatkan guru hanya bergantung pada buku siswa yang diterbitkan oleh pemerintah. Padahal isi dari buku yang merupakan proyek nasional tersebut belum tentu sesuai dengan kondisi siswa di daerahdaerah. Seharusnya buku siswa dari pusat tidak diajarkan secara langsung tetapi perlu dilakukan modifikasi disesuaikan dengan kondisi budaya masyarakat sekitar.

Terdapat beberapa penelitian terdahulu yang mengkaji tentang sumber belajar IPS. Penelitian Larasati (2019) mengkaji tentang dampak pembangunan salah satu objek wisata di daerah Ngawi dan potensinya sebagai sumber materi pembelajaran IPS SD. Hasil kajian tersebut menyatakan bahwa kehidupan ekonomi masyarakat di obyek wisata tersebut memiliki potensi sebagai sumber pembelajaran IPS SD. Penelitian selanjutnya dilakukan oleh Ruslan (2019) yang melakukan rekonstruksi terhadap rumah masa kerajaan Majapahit di salah satu situs kerajaan Majapahit Trowulan. Hasil penelitian menyatakan bahwa rekonstruksi rumah masa kerajaan Majapahit sangat berpotensi untuk dijadikan bahan pengayaan materi ajar mata kuliah pendidikan IPS bagi mahasiswa. Penelitian selanjutnya dilakukan oleh Widodo, Akbar, \& Sujito (2017) yang mengkaji tentang sebuah buku filsafat Jawa sebagai sumber belajar IPS. Hasil penelitian menyatakan bahwa dalam falsafah Jawa terdapat banyak nilai-nilai karakter yang dapat diimplementasikan dalam pembelajaran IPS di sekolah. Penelitian serupa juga telah dilakukan dengan mengkaji nilai-nilai budaya dalam kesenian Dongkrek (Hanif, 2016). Penelitian tersebut mengkaji nilai budaya sebagai sumber pendidikan karakter. Hasil kajian dalam penelitian tersebut menyatakan bahwa kesenian dongkrek memiliki nilai-nilai; kerohanian, spiritual, moral, kepahlawanan, kepemimpinan, keadilan, kesejahteraan, dan estetika. Nilai-nilai tersebut dapat dijadikan sumber pendidikan karakter terutama dalam menjalin hidup bermasyarakat, menumbuhkan jiwa kepemimpinan, jiwa kepahlawanan, ikhlas dan kesetiaan. Nilai budaya tersebut penting untuk ditumbuh kembangkan mengingat semakin gencarnya arus budaya asing. Jika hal ini dibiarkan bukan tidak mungkin budaya lokal akan sirna.

Penelitian ini akan mengkaji tentang nilai-nilai budaya pada ritual Perang Topat. Analisis terhadap nilai-nilai budaya diperlukan untuk mencari sumber belajar IPS berbasis kearifan lokal di wilayah Lombok Barat. Pendekatan kearifan lokal dipilih karena merupakan salah satu cara agar pembelajaran IPS lebih kontekstual. Penggunaan pendekatan kontekstual dalam pembelajaran IPS memiliki banyak manfaat, salah satu diantaranya adalah menyederhanakan konsep IPS yang cenderung abstrak. Selain itu hal terpenting dalam pembelajaran kontekstual adalah kebermaknaan pembelajaran tersebut dalam kehidupan siswa sehari-hari. Maka dari itu penggunaan lingkungan budaya masyarakat sebagai sumber belajar IPS tidak lain bertujuan agar siswa dapat mengambil pelajaran dari peristiwa yang dilami, dilihat dan dirasakan. Salah satu kearifan lokal daerah Lombok Barat adalah ritual Perang Topat. Ritual ini tidak dapat dijumpai di daerah lain karena kunikannya. Fenomena unik dalam ritual Perang Topat patut dikaji yang berpotensi menjadi salah satu sumber belajar IPS di sekolah dasar. Melalui pembelajaran IPS berbasis kearifan lokal peserta didik diharapkan tidak tercabut dari akar budayanya. Maka dari itu dalam penelitian ini akan dikaji tentang potensi ritual Perang Topat sebagai sumber 
pembelajaran IPS di sekolah dasar. Masalah utama dalam penelitian ini adalah nilai-nilai apa saja yang terdapat pada ritual Perang Topat? Apakah nilai budaya ritual Perang Topat relevan dengan KI/KD atau tema pembelajaran IPS di sekolah dasar? apa saja topik pembelajaran yang relevan dengan nilai budaya ritual Perang Topat?

\section{Metode Penelitian}

Jenis penelitian yang digunakan dalam penelitian ini adalah kualitatif dengan pendekatan etnometodologi. Penelitian kualitatif menurut Sugiyono (2008:19) merupakan penelitian yang mendalam tentang suatu objek melalui apa yang dilihat peneliti, didengar, dirasakan dan ditanyakan. Menurut Moleong (2009: 24) etnometodologi bukanlah metode yang digunakan untuk mengumpulkan data tetapi merupakan sebuah kajian tentang bagaimana individu menciptakan dan memahami kehidupannya sehari-hari. Maka dari itu dalam penelitian ini penggunaan pendekatan etnometodologi dimanfaatkan untuk menggali, memahami, menjelaskan dan menguraikan nilai-nilai budaya yang terdapat pada ritual Perang Topat untuk dijadikan sumber pembelajaran IPS. Pengumpulan data melalui observasi dan studi kepustakaan. Analisis data menggunakan model analisis tema Spradley. Analisis dilakukan bersama-sama dengan pengumpulan data. Tahapan analisisnya adalah analisis domein, analisis taksonomi, analisis komponensial, dan analisis tema kultural. Langkah-langkah penelitian antara lain tahap deskripsi, tahap reduksi, dan menemukan. Tahap deskripsi dilakukan dengan mengumpulkan berbagai macam data penelitian baik melalui pengamatan di lapangan, wawancara maupun mencari literatur. Pada tahap reduksi yang dilakukan peneliti menentukan fokus permasalahan dari berbagai data yang telah terkumpul. Setelah itu masuk pada tahap seleksi. Pada tahap ini dilakukan pemilahan dan pemilihan data yang sesuai dengan topik penelitian. Tahap terakhir adalah menemukan. Pelaksanaan penelitian diawali dengan memilih situasi sosial, melaksanakan observasi partisipan, melakukan wawancara, observasi deskriptif, melakukan analisis domain, observasi terfokus, analisis taksonomi, observasi terseleksi, analisis komponensial, melakukan analisis tema, temuan budaya dan membuat laporan penelitian Sugiyono (2008: 254). Setelah dilakukan analisis terhadap nilai-nilai budaya langkah selanjutnya adalah melakukan analisis terhadap KI/KD dan tema pembelajaran IPS di sekolah dasar. Masalah yang ingin ditemukan dalam penelitian ini adalah nilai-nilai apa yang terdapat pada ritual Perang Topat dan potensinya sebagai sumber belajar IPS di sekolah dasar. Instrumen yang digunakan dalam pengumpulan data berupa rubrik dan panduan observasi. Pengecekan keabsahan temuan adalah dengan menggunakan triangulasi sumber. Target penelitian ini adalah menggali nilai-nilai budaya di balik ritual Perang Topat serta menganalisis relevansinya dengan topik pembelajaran IPS di sekolah dasar. Sumber penelitian ini terdiri dari sumber primer dan sumber sekunder. Sumber primer dikumpulkan melalui observasi dan wawancara, sedangkan sumber sekunder dilakukan dengan mengkaji pustaka yang relevan.

\section{Hasil dan Pembahasan Hasil Penelitian}

Penelitian ini dilakukan untuk menggali nilai-nilai budaya ritual Perang Topat serta analisis relevansinya dengan topik pembelajan IPS di sekolah dasar. Tujuan utamanya adalah menggali nilai-nilai budaya lokal sebagai sumber belajar IPS. Melalui pendekatan kearifan lokal diharapkan pembelajaran menjadi lebih kontekstual dan bermakna bagi peserta didik. Melalui model semacam ini peserta didik dapat belajar lebih dekat dengan lingkungan budaya sekitar. Harapannya peserta didik dapat mengambil makna dan nilai-nilai edukasi maupun karakter dari fenomena yang telah dipelajari.

\section{Nilai-nilai budaya dalam ritual Perang Topat}

a. Nilai kompromi 
Nilai kompromi dalam ritual Perang Topat ditunjukkan dengan adanya kesepakatan umat Hindu dengan umat Muslim yang menggunakan hewan kerbau sebagai korban dalam rangkaian ritual. Orang Hindu sangat menghormati sapi sedangkan orang Islam tidak makan babi. Penggunaan kerbau sebagai salah satu kelengkapan merupakan wujud kompromi antara dua agama tersebut. Kerbau tersebut kemudian disembelih untuk dijadikan lauk pada saat ritual. Petugas yang bertugas menyembelih kerbau sesuai dengan kesepakatan berasal dari orang Islam. Di dalam nilai kompromi ini juga terdapat nilai pengorbanan dan semangat persatuan dalam mencapai kesepakatan demi kepentingan bersama.

b. Nilai religius

Nilai religius dalam ritual Perang Topat diwujudkan dalam bentuk simbol ritual. Salah satunya terdapat dalam perlengkapan ritual yang berupa lamak atau tikar lengkap dengan peralatan ibadah umat Islam. Tikar tersebut diikat dan dimasukkan dalam peti. Simbol ini bermakna sebagai pengingat agar orang Islam tidak lupa dengan kewajiban shalat lima waktu. Selain itu makna ritual Perang Topat adalah sebagai salah satu permohonan kepada Tuhan YME untuk memperoleh kesuburan, keselamatan dan kesejahteraan. Dalam pandangan umat Muslilm ritual Perang Topat bermakna ziarah kubur. Di dalam ziarah mengandung sebuah nilai yang berfungsi sebagai pengingat bahwa semua manusia pada akhirnya akan mati. Melalui ingat pada kematian manusia diharapkan selalu konsisten untuk berbuat baik. Untuk itu manusia harus berlomba-lomba dalam hal kebaikan karena sebaik baik manusia adalah yang bermanfaat bagi sesamanya.

c. Nilai historis

Nilai historis dalam ritual Perang Topat terdapat pada ritual Ngeliningan kaoq sebelum ritual Perang Topat dimulai. Ngeliningan kaoq merupakan ritual napak tilas untuk memperingati perjalanan leluhur masyarakat setempat yaitu Datu Sumilir. Pada saat ritual ini umat Hindu dan umat Islam bersama-sama membawa kerbau mengelilingi Kemaliq dan Gadoh sebanyak tiga kali. Melalui ritual ini masyarakat dapat mengenang perjuangan dan perjalanan hidup tokoh sejarah. Masyarakat dapat belajar bagaimana proses penyebaran dan perkembangan agama Hindu dan Islam di wilayah Lingsar Lombok Barat.

d. Nilai kebersamaan dan persamaan derajat

Nilai kebersamaan dan persamaan derajat pada ritual Perang Topat ditunjukkan pada saat pelaksanaan ritual. Masyarakat Hindu dan Muslim saling menyadari peran dan kedudukannya masing-masing. Tidak ada golongan yang merasa lebih unggul sehingga ingin melakukan ritual terlebih dahulu. Mereka melakukan ritual secara bersama-sama. Topat yang telah diberi doa oleh Mangku bersama kelengkapan ritual lainnya dibawa ke depan pintu Kemaliq kemudian diberikan kepada masyarakat Muslim dan Hindu untuk saling melempar. Mereka melakukan ritual secara bersama-sama walaupun mempunyai keyakinan dan makna yang berbeda dalam sebuah ritual yang sama.

e. Nilai gotong royong

Nilai gotong royong ditunjukkan pada saat sebelum ritual. Masyarakat Hindu dan Muslim secara bersama-sama melakukan persiapan ritual seperti membersihkan tempat ritual serta menyediakan segala kebutuhan ritual. Kedua kelompok masyarakat tersebut saling bahu membahu dalam mempersiapkan pelaksanaan ritual. Mereka rela berbagi beban agar ritual terlaksana dengan baik. Semangat gotong royong ini merupakan salah satu nilai yang terus dipupuk oleh masyarakat dalam kehidupan bermasyarakat.

f. Nilai musyawarah dan kekeluargaan

Nilai kekeluargaan ditunjukkan dengan adanya silaturahmi antara tokoh agama Hindu dengan Islam sebelum pelaksanaan ritual. Kedua golongan tersebut berkomunikasi dalam mempersiapkan ritual agar berjalan dengan lancar. Komunikasi antar tokoh agama di sini merupakan salah satu kunci sukses dalam melaksanakan ritual bersama. Melalui 
musyawarah bersama ini segala sesuatu yang berkaitan dengan jalannya ritual dapat dipecahkan bersama. Masyarakat menjunjung tinggi nilai musyawarah dalam mencapai kesepakatan. Tidak ada voting dalam menyelesaikan berbagai persoalan di sini. Pengambilan keputusan atas dasar mufakat sehingga semua pihak dapat menerima dengan lapang dada. Semua pihak merasa bertanggung jawab dan mentaati hasil musyawarah bersama.

g. Nilai toleransi

Nilai toleransi ditunjukkan dengan sikap saling menghormati dan tenggang rasa antara warga Hindu dengan Muslim pada saat ritual. Mereka dapat melakukan ritual bersama tanpa ada yang merasa terganggu. Umat Hindu memaknai ritual Perang Topat sebagai sebuah dharma dalam mendekatkan diri kepada Tuhan YME, sedangkan masyarakat Muslim memaknai ritual sebagai bentuk ziarah terhadap tokoh penyebar agama Islam di wilayah Lingsar. Baik umat Islam maupun Hindu percaya bahwa ritual ini mempunyai unsur magis dan sakral. Walaupun dari segi keyakinan berbeda namun dua kelompok dapat melakukan ritual secara bersamaan. Kedua kelompok masyarakat saling menghargai perbedaan satu sama lain. Nilai toleransi merupakan nilai terpenting dalam menjaga kerukunan antara umat Islam dengan penganut agama Hindu di wilayah Lingsar.

\section{Analisis KI/KD dan Tema pembelajaran IPS di Sekolah Dasar}

Berdasarkan Peraturan Menteri Pendidikan dan Kebudayaan Republik Indonesia Nomor 37 tahun 2018 Mendikbud (2018) yang merupakan perubahan atas peraturan sebelumnya Kompetensi Inti (KI) dan Kompetensi Dasar (KD) Kurikulum 2013 untuk mata pelajaran Ilmu Pengetahuan Sosial (IPS) pada jenjang SD/MI baru diajarkan jika siswa telah berada di kelas IV. Untuk kelas I sampai dengan kelas III terintegrasi dan terpadu sehingga tidak terlihat lagi kompetensi dasar tiap mata pelajaran. Secara umum tujuan kurikulum 2013 mencakup empat kompetensi, yaitu (1) kompetensi sikap spiritual yang termuat dalam KI 1, (2) sikap sosial yang termuat dalam KI 2, (3) pengetahuan yang termuat dalam KI 3, dan (4) keterampilan yang termuat dalam KI 4. Keempat kompetensi tersebut dalam praktiknya dapat dicapai melalui kegiatan intrakurikuler, kokurikuler, maupun ekstrakurikuler. Rumusan Kompetensi Sikap Spiritual pada KI 1 di kelas IV adalah menerima, menghargai, dan menjalankan ajaran agama yang dianutnya". Sedangkan kompetensi Sikap Sosial pada KI 2 berbunyi "menunjukkan perilaku jujur, disiplin, tanggung jawab, santun, peduli, dan percaya diri dalam berinteraksi dengan keluarga, teman, guru, dan tetangganya". Rumusan kompetensi spiritual di kelas V tidak ada perbedaan dengan kelas IV, namun dalam rumusan sikap sosial terdapat sedikit perbedaan. Untuk di kelas $\mathrm{V}$ siswa dalam berinteraksi tidak hanya dengan keluarga, teman, guru dan tetangga tetapi juga berkaitan dengan cinta tanah air. Begitu juga dengan kompetensi spiritual pada kelas IV sedangkan kompetensi sosialnya sama dengan kelas V. Kedua kompetensi tersebut dapat dicapai melalui indirect teaching, antara lain melalui keteladanan, pembiasaan, dan budaya sekolah yang disesuaikan karakteristik mata pelajaran maupun kebutuhan dan kondisi peserta didik. Pembelajaran tidak langsung pada kedua kompetensi tersebut merupakan sarana dalam mengembangkan dan menginternalisasi nilai-nilai karakter terhadap peserta didik. Maka dari itu KI 1 dan KI 2 dalam mata pelajaran IPS tidak perlu diturunkan menjadi KD tidak seperti KI 3 dan KI 4 karena telah terintegrasi dalam setiap pembelajaran.

Rumusan kompetensi pengetahuan pada KI 3 di kelas IV yaitu "memahami pengetahuan faktual dengan cara mengamati dan menanya berdasarkan rasa ingin tahu tentang dirinya, makhluk ciptaan Tuhan dan kegiatannya, dan benda-benda yang dijumpainya di rumah, di sekolah dan tempat bermain". Rumusan kompetensi pengetahuan pada KI 3 di kelas V juga terjadi sedikit perbedaan. Untuk di kelas $\mathrm{V}$ siswa tidak hanya diarahkan untuk memahami pengetahuan secara faktual tetapi juga dengan cara konseptual. Sedangkan kompetensi pengetahuan di kelas VI tidak ada perbedaan dengan kelas V. Rumusan kompetensi keterampilan pada KI 4 di kelas IV berbunyi "Menyajikan pengetahuan faktual dalam bahasa yang jelas, sistematis dan logis, dalam karya yang estetis, dalam gerakan yang mencerminkan 
anak sehat, dan dalam tindakan yang mencerminkan perilaku anak beriman dan berakhlak mulia". Terdapat sedikit perbedaan rumusan kompetensi keterampilan pada KI 4 di kelas $\mathrm{V}$ dengan di kelas IV. Untuk di kelas V siswa diharapkan tidak hanya mampu menyajikan pengetahuan secara faktual saja tetapi juga secara konseptual. Selain itu siswa di kelas V telah diarahkan untuk memiliki kemampuan berpikir kritis. Sedangkan rumusan kompetensi keterampilan di kelas VI tidak ada perbedaan dengan kelas V. Kompetensi pengetahuan (KI 3) dan kompetensi keterampilan (KI 4) masih terlalu umum sehingga perlu dipecah menjadi beberapa kompetensi dasar (KD).

KI 3 di kelas IV, V, dan VI masing-masing dibagi menjadi 4 KD. KD pada KI 3 di kelas IV antara lain KD 3.1 berisi materi tentang karakteristik ruang dan pemanfaatan sumber daya alam. KD 3.2 berisi materi tentang keragaman sosial, ekonomi, agama dan budaya. KD 3.3 berisi materi tentang kegiatan ekonomi. KD 3.4 berisi tentang materi sejarah kerajaan Hindu/Budha/Islam dan pengaruhnya terhadap kehidupan masyarakat. KI 3 di kelas V antara lain: KD 3.1 mengkaji tentang karakteristik geografis Indonesia sebagai Negara kepulauan dan agraris. KD 3.2 mengkaji tentang bentuk interaksi manusia dengan lingkungan. KD 3.3 mengkaji tentang peran ekonomi dalam menyejahterakan kehidupan masyarakat. KD 3.4 mengkaji tentang masa penjajahan dan upaya bangsa Indonesia mempertahankan kemerdekaan. KI 3 di kelas VI antara lain KD 3.1 membahas tentang karakteristik geografis dan kehidupan sosial, ekonomi, budaya, dan politik dalam lingkup ASEAN. KD 3.2 membahas tentang perubahan sosial budaya dan modernisasi di Indonesia. KD 3.3 membahas tentang peran Indonesia dalam kerjasama internasional dalam lingkup ASEAN. KD 3.4 membahas tentang makna proklamasi, upaya mempertahankan kemerdekaan dan pembangungan bangsa yang sejahtera. KD pada KI 4 diuraikan sebanyak KD yang ada pada KI 3. KD pada ranah keterampilan merupakan wujud aktualisasi yang diperoleh siswa selama pembelajaran pada ranah pengetahuan seperti menyajikan pengetahuan, membuat karya dan keterampilan lainnya sehingga tidak perlu diuraikan satu per satu.

Pembelajaran IPS di sekolah dasar dengan adanya kurikulum 2013 revisi tidak lagi mengenal mata pelajaran. Pendekatan yang dipakai dalam pembelajaran adalah tematik terpadu. Namun demikian kompetensi inti dan kompetensi dasar tiap mata pelajaran masih terlihat jelas. Berikut ini tema pembelajaran yang mengandung muatan materi pendidikan IPS di sekolah dasar. Tema pendidikan IPS di kelas IV antara lain tema 1 "indahnya kebersamaan", tema 4 "berbagai pekerjaan", tema 5 "pahlawanku", Tema 7 "indahnya keragaman di negeriku", tema 8 "daerah tempat tinggalku" dan tema 9 "kayanya negeriku". Tema 1 dibagi menjadi 3 subtema antara lain "keragaman budaya bangsaku", "kebersamaan dalam keberagaman" dan "bersyukur atas keberagaman". Tema 4 dibagi menjadi subtema "jenis-jenis pekerjaan", "pekerjaan di sekitarku" dan "pekerjaan orang tuaku". Tema 5 dibagi menjadi sub tema: "perjuangan para pahlawan", "pahlawanku kebanggaanku", dan "sikap kepahlawanan". Tema 7 dibagi menjadi 3 subtema antara lain "keragaman suku bangsa dan agama di negeriku", "indahnya keragaman budaya di negeriku", dan "indahnya persatuan dan kesatuan negeriku". Tema 8 dibagi menjadi 3 subtema "lingkungan tempat tinggalku", "keunikan daerah tempat tinggalku", dan "bangga terhadap daerah tempat tinggalku". Tema di kelas V yang mengandung mauatan pendidikan IPS terdapat pada tema 7 dan 8 yaitu "peristiwa dalam kehidupan" dan "lingkungan sahabat kita". Tema 7 dibagi menjadi beberapa subtema antara lain "peristiwa kebangsaan masa penjajahan", "peristiwa kebangsaan seputar proklamasi kemerdekaan", dan "peristiwa mengisi kemerdekaan". Tema 8 terdiri dari subtema "manusia dan lingkungan", "perubahan lingkungan" dan "usaha pelestarian lingkungan". Tema yang mengandung muatan pendidikan IPS di kelas VI terdapat pada tema 2 dan 4, yaitu "persatuan dalam perbedaan" dan "globalisasi". Tema 2 dibagi menjadi 3 subtema antara lain "rukun dalam perbedaan", "bekerja sama mencapai tujuan", dan "bersatu kita teguh". Sedangkan tema 4 dibagi menjadi subtema "globalisasi di sekitarku", "globalisasi dan manfaatnya", serta "globalisasi dan cinta tanah air". 


\section{Pembahasan}

\section{Makna Filosofis Perang Topat}

Perang Topat merupakan budaya lokal yang masih dilestarikan oleh masyarakat Lombok Barat. Perang Topat dilaksanakan oleh suku Sasak yang menganut agama Islam Wetu Telu. Upacara ini dilaksanakan bersamaan dengan upacara Pujawali yang rayakan oleh suku Bali penganut agama Hindu (Wirata I, 2015). Persinggungan antara dua kelomok etnis tersebut telah terjadi sejak ratusan tahun yang lalu. Mengingat daerah Lombok dan sekitarnya adalah wilayah kekuasaan kerajaan Karangasem Bali (Bahri, 2018). Maka dari itu suku Sasak dalam perkembangan sejarahnya banyak mendapat pengaruh dari kebudayaan Bali. Peperangan demi peperangan telah dilakukan oleh masyarakat Lombok agar terlepas dari pengaruh kerajaan Bali. Konflik kedua etnis ini tidak hanya berkaitan dengan aspek politik tetapi juga membawa simbol agama (Paramita \& Suadnya, 2018). Interaksi budaya antara kedua etnis tersebut melahirkan budaya baru yang sangat unik yaitu ritual Perang Topat. Selain sebagai simbol perdamaian antara kedua belah pihak, ritual Perang Topat bertujuan untuk memperoleh keselamatan, kedamaian, dan ketenteraman hidup. Keselamatan dapat tercapai jika ada perdamaian. Jadi dapat dipahami bahwa ritual Perang Topat adalah simbol perdamaian bukan simbol peperangan.

Pada saat puncak ritual Perang Topat kedua kelompok dengan menggunakan pakaian adat masing-masing saling serang. Media yang digunakan adalah ketupat. Maka dari itu ritual ini dinamakan Perang Topat. Ketupat yang digunakan dalam ritual Perang Topat adalah ketupat yang dimasak serta telah diberi doa (disucikan). Ketupat yang digunakan hanyalah ketupat yang telah gunakan dalam rangkaian ritual, tidak diperbolehkan memakai ketupat dari luar. Ketupat yang telah disucikan dalam ritual kemudian digunakan sebagai alat perang. Keduanya saling lempar kemudian ketupatnya direbut kembali untuk dibawa pulang. Pada saat ini terjadi interaksi langsung sehingga keduanya dapat berbalasan. Ketupat yang didapatkan pada ritual tersebut dipercaya dapat membawa berkah. Pelaksanaan ritual Perang Topat mencerminkan kebersamaan, karena mulai dari perencanaan hingga puncak festival terjadi komunikasi baik verbal maupun non verbal antara kedua belah pihak (Acim \& Yaqinah, 2019).

Ritual Perang Topat menimbulkan adanya integrasi budaya antara etnis Sasak penganut agama Islam wetu telu dengan etnis Bali yang menganut agama Hindu. Ritual Perang Topat sarat dengan nilai-nilai edukasi yang terdapat dalam simbol ritual. Berbagai simbol ritual upacara mengandung makna filosofis yang mendalam. Melalui berbagai simbol ritual, Perang Topat mengajarkan pendidikan melalui alam terbuka. Makna simbolis dalam Perang Topat selain sebagai ritual keagamaan juga mengandung nilai-nilai sosial dan budaya. Nilai sosial yang terkandung dalam Perang Topat antara lain: kerukunan, toleransi, kerjasama, kedisiplinan dan keharmonisan hidup. Melalui ritual ini konflik antara kedua belah pihak dapat dihindari, karena telah terjadi interaksi sosial yang berjalan dengan baik. Hal ini tidak lepas dari pengaruh kuatnya tokoh agama Hindu dan agama Islam dalam melakukan komunikasi agar ritual dapat berjalan lancar (Jayadi et al., 2017).

Makna simbolis dalam Perang Topat adalah sebuah kerukunan, dimana dua agama berbeda dapat melaksanakan ritual secara bersamaan diwaktu dan tempat yang sama. Peperangan yang disimbolkan dalam Perang Topat tidak menimbulkan kerusakan atau kerugian diantara kedua belah pihak, namun semakin menumbuhkan perasaan kekeluargaan, harmoni dan silaturahmi antar dua agama yang berbeda (Suprapto, 2017). Hal ini tentunya peristiwa unik yang tidak dapat ditemukan di daerah lain. Dari sini dapat dipahami bahwa ritual Perang Topat dapat menjadi simbol persatuan dan kesatuan bangsa ditengah-tengah semakin merebaknya sikap intoleran yang dialami anak bangsa. Ritual Perang Topat diselenggarakan dengan tujuan untuk memohon keselamatan, kesuburan dan kemakmuran bagi masyarakat Lombok. Kesuburan dilambangkan dengan adanya nasi yang melimpah ruah, sedangkan keselamatan dan ketentraman terlihat dari adanya interaksi dan suasana damai pada saat penyelenggaraan ritual. Persatuan dan kesatuan dapat terpupuk pada saat pelaksanaan ritual yang penuh dengan 
toleransi antara Islam Wetu Telu dengan Hindu. Dengan adanya persatuan dan kerukunan antara dua golongan tersebut menghilangkan adanya konflik sehingga hidup damai dan tenteram akan tercipta. Ritual Perang Topat dari segi estetika mempunyai nilai seni dan keindahan yang tinggi. Hal ini merupakan potensi wisata daerah yang menjanjikan. Jika dapat dikelola dengan baik ritual budaya ini akan memancing kedatangan wisatawan dari dalam maupun luar negeri. Manfaatnya adalah meningkatnya perekonomian warga sekitar.

Ritual Perang Topat merupakan hasil cipta, rasa dan karsa manusia yang memiliki makna simbolik. Makna yang terkandung dalam ritual Perang Topat meliputi religi, edukasi dan ilmiah (Yasa, 2020). Ritual Perang Topat jika ditinjau dari segi filsafat mengandung nilai etika, estetika dan logika. Nilai etika yang terdapat dalam ritual Perang Topat adalah nilai religius yang berisi aturan dan pedoman hidup bagi manusia. Nilai logika yang terdapat dalam Perang Topat adalah kesuburan. Sarana Perang Topat yang terbuat dari ketupat berisi nasi. Logikanya jika nasi yang didapatkan pada ritual tersebut ditabur di sawah akan menjadi humus atau pupuk yang menyuburkan bagi sawah petani. Di sinilah logikanya Perang Topat dapat mendatangkan kesuburan. Interaksi budaya antara etnis Sasak Islam dengan Hindu Bali dalam ritual Perang Topat tidak menyebabkan keduanya kehilangan ciri budayanya. Kedua belah pihak masih mempertahankan ciri khasnya masing-masing seperti pakain dan perlengkapan ritual, walaupun dalam beberapa hal tampak terlihat adanya persamaan (Marjan \& Hariati, 2018). Pelaksanaan ritual Perang Topat yang telah ditentukan waktu dan tempatnya wajib dipatuhi. Jika hal ini dilanggar maka akan menimbulkan dampak yang tidak baik terhadap masyarakat. Kepatuhan terhadap aturan penyelenggaraan ritual ini terkandung nilai disiplin. Kedisiplinan harus dipatuhi agar keharmonisan dan keselarasan hidup dapat tercapai. Pelanggaran terhadap aturan akan berdampak buruk terhadap kehidupan bermasyarakat.

\section{Relevansi nilai budaya ritual Perang Topat dengan topik pembelajaran IPS di sekolah dasar}

Pendidikan IPS memiliki tujuan untuk membentuk warga Negara yang baik. Salah satu indikator warga Negara yang baik adalah mampu hidup berdampingan dan mempunyai sikap toleransi dalam perbedaan baik dari segi sosial maupun budaya. Jika kita mau mengkaji lebih dalam pada hakikatnya jauh sebelum pendidikan multikultural dikampanyekan oleh bangsa Barat, bangsa Indonesia telah mempraktikkannya dalam hidup bermasyarakat. Salah satunya melalui ritual perang Topat. Ada makna persatuan dalam Perang Topat yang merupakan wujud pendidikan nasionalisme (Suadnya \& Paramita, 2018). Pendidikan multikultural mengedepankan kesetaraan tanpa memandang gender, status sosial, etnis, agama dan berbagai macam label kultural. Selain itu pendidikan multikultural berusaha mengembangkan sikap kepekaan budaya, toleransi budaya, dan terampil dalam menghindari konflik akibat perbedaan budaya. Adanya pengetahuan terhadap budaya orang lain dapat meningkatkan kesadaran dalam perspektif kultural sehingga membuat seseorang menjadi lebih bijak. Melalui pembelajaran multikultural seseorang dapat belajar dalam memperbaiki stereotip, kesalah pahaman dan cara pandang yang salah terhadap kelompok etnis tertentu. Tujuan utama dari pembelajaran ini adalah adanya penghargaan terhadap dinamika kultural dan perbedaan budaya. Ironisnya adalah pendidikan multikultural yang telah diajarkan oleh para leluhur seringkali tidak kita sadari. Salah satu penyebabnya adalah semakin rendahnya pengetahuan kita terkait dengan sejarah bangsanya sendiri. Hal ini merupakan salah satu implikasi dari pemikiran yang menganggap belajar sejarah itu tidak penting, sehingga nilai-nilai historis yang sarat dengan pendidikan karakter tidak dapat dipahami. Terlebih lagi dengan sejarah lokal yang merupakan salah satu bagian dari perkembangan suatu daerah kurang diminati oleh kaum muda. Implikasinya adalah banyak kaum muda yang tidak tahu sejarah lokal di daerahnya masing-masing. Hal inilah yang menyebabkan kaum muda suku Sasak di daerah Lombok mengalami krisis identitas karena tidak tahu aturan budaya (Team Berugaq Institute, 2015). Kondisi di atas diperparah dengan rendahnya minat baca di kalangan kaum muda, terlebih lagi dengan bacaan yang berisi tentang 
sejarah. Hal ini sungguh ironis mengingat membaca adalah merupakan salah satu unsur terpenting dalam kegiatan pembelajaran (Widodo et al., 2020).

Pendidikan IPS yang di dalamnya terdapat muatan materi sejarah seharusnya tidak hanya mengajarkan sejarah nasional saja, tetapi juga memperhatikan aspek sejarah lokal di mana siswa berada. Melalui pembelajaran semacam ini peserta didik dapat merasakan manfaat dari materi yang telah dipelajari. Hal ini dikarenakan salah satu manfaat dari pendidikan IPS adalah sebagai sarana untuk mengajarkan kepada peserta didik agar menyadari potensi yang ada di wilayahnya masing-masing. Melalui pembelajaran IPS yang bersumber pada ritual Perang Topat peserta didik diajarkan untuk mengenali potensi yang ada dalam Perang Topat. Salah satu potensi yang ada dalam ritual Perang Topat adalah potensi wisata. Hal ini dikarenakan ritual Perang Topat mengandung nilai-nilai estetika dan budaya yang tinggi. Peserta didik dapat dilatih untuk berpikir kritis membaca peluang berdasarkan potensi yang ada di daerahnya masing-masing. Langkah konkrit pemanfaatan ritual Perang Topat sebagai sumber belajar antara lain: 1) pengembangan bahan ajar yang bersumber pada nilai-nilai karakter dalam ritual Perang Topat, 2) menganalisis $\mathrm{KI} / \mathrm{KD}$ atau tema pembelajaran yang relevan dengan nilai-nilai budaya ritual Perang Topat, dan 3) pemanfaatan ritual Perang Topat sebagai sumber belajar langsung. Peserta didik dapat belajar secara langsung bagaimana masyarakat yang berbeda keyakinan dapat melakukan kerj sama, hidup rukun, bersikap toleransi dengan rasa kekeluargaan yang tinggi.

Pendidikan IPS tidak hanya menekankan pada aspek kognitif semata. Program pendidikan IPS mencakup empat dimensi yaitu dimensi pengetahuan (knowledge), dimensi keterampilan (skills), dimensi nilai dan sikap (values and attitudes), dan dimensi tindakan (Sapriya, 2017: 49-56). Keempat dimensi tersebut dalam kurikulum 2013 telah difasilitasi dalam bentuk kompetensi inti dan kompetensi dasar mulai dari KI 1 sampai dengan KI 4. Berdasarkan analisis terhadap KI/KD pendidikan IPS di sekolah dasar terdapat beberapa topik pembelajaran yang berkaitan erat dengan nilai-nilai budaya di kelas IV. Kompetensi dasar tersebut antara lain KD 3.2 berisi materi tentang keragaman sosial, ekonomi, agama dan budaya dan KD 3.4 berisi tentang materi sejarah kerajaan Hindu/Budha/Islam dan pengaruhnya terhadap kehidupan masyarakat. Keterkaitan antara nilai-nilai budaya pada ritual Perang Topat dengan KD 3.2 terletak pada nilai toleransi. Melalui sikap toleransi peserta didik diajarkan untuk menghormati dan menghargai keragaman dalam kehidupan bermasyarakat baik dari segi sosial, ekonomi, agama maupun budaya. Siswa diharapkan mampu menerapkan sikap toleransi dari materi yang diajarkan melalui pembelajaran IPS. Sikap toleransi tersebut dapat siswa saksikan melalui ritual yang dilakukan oleh umat Islam dan Hindu di Lombok Barat. Melalui ritual tersebut siswa dapat belajar secara langsung bagaimana toleransi yang diterapkan oleh masyarakat yang berbeda keyakinan. Keterkaitan antara nilai budaya ritual Perang Topat dengan KD 3.4 terletak pada nilai historisnya. Ritual tersebut sarat dengan edukasi dalam bidang sejarah karena pada hakikatnya umat Muslim menganggap bahwa ritual tersebut merupakan bentuk ziarah terhadap tokoh penyebar agama Islam di wilayah Lingsar Lombok Barat. Dalam ritual Perang Topat terdapat salah satu agenda ritual Ngeliningan kaoq (membawa kerbau mengelilingi Kemaliq dan Gadoh sebanyak tiga kali) yang menggambarkan perjalanan/napak tilas tokoh penyebar agama Islam. Melalui ritual tersebut siswa dapat belajar bagaimana perjalanan Datu Sumilir dalam menyebarkan Islam. Dari sini siswa dapat belajar proses masuk dan perkembangan Islam di Lombok Barat.

Tema pembelajaran IPS yang relevan dengan nilai-nilai budaya Perang Topat antara lain: tema 1 "indahnya kebersamaan", tema 7 "indahnya keragaman di negeriku" dan tema 8 "daerah tempat tinggalku" yang terdapat di kelas IV. Tema 1 dibagi menjadi 3 subtema antara lain "keragaman budaya bangsaku", "kebersamaan dalam keberagaman" dan "bersyukur atas keberagaman". Tema 7 dibagi menjadi 3 subtema antara lain "keragaman suku bangsa dan agama di negeriku", "indahnya keragaman budaya di negeriku", serta "indahnya persatuan dan kesatuan negeriku". Tema 8 dibagi menjadi 3 subtema "lingkungan tempat tinggalku", "keunikan daerah tempat tinggalku", dan "bangga terhadap daerah tempat tinggalku". Nilai-nilai 
budaya ritual Perang Topat yang dapat dimplementasikan pada tema 1 dan 7 antara lain nilai kebersamaan, toleransi, religius, kekeluargaan, gotong royong, persatuan dan kesatuan serta cinta damai. Selain itu nilai historis dari ritual Perang Topat dapat dimanfaatkan untuk memahami perkembangan agama Hindu dan Islam di wilayah Lombok. Pada tema 8 terdapat subtema "keunikan derah tempat tinggalku". Pada subtema ini peserta didik diajarkan bagaimana mengenali keunikan daerah tempat tinggal mereka. Melalui pembelajaran ini peserta didik diharapkan mampu menyadari potensi diri dan daerah di mana mereka tinggal.

Tema selanjutnya yang relevan dengan nilai-nilai budaya ritual Perang Topat adalah tema 2 "persatuan dalam perbedaan" yang berada di kelas VI. Di dalam tema tersebut terdapat 3 subtema antara lain "rukun dalam perbedaan", "bekerja sama mencapai tujuan", dan "bersatu kita teguh". Tema "persatuan dalam perbedaan" dapat dikaitkan dengan nilai kompromi, nilai kebersamaan dan persamaan derajat, nilai gotong royong, nilai kekeluargaan, serta nilai toleransi yang ada pada ritual Perang Topat. Melalui nila-nilai budaya tersebut peserta didik dapat diajarkan bagaimana memupuk persatuan dan persatuan bangsa di dalam kemajemukan. Nilai kompromi mengajarkan bagaimana peserta didik dapat menerima perbedaan dan berlapang dada demi tujuan bersama. Melalui nilai kebersamaan dan persamaan derajat siswa dapat belajar secara langsung bagaimana dua kelompok yang berbeda dapat melakukan kegiatan secara bersama-sama dengan tidak mengutamakan kepentingan kelompoknya sendiri. Begitu juga dengan nilai kekeluargaan peserta didik dapat mengamati secara langsung keeratan sosial yang dijalin oleh masyarakat yang berbeda keyakinan. Nilai gotong royong yang ditunjukkan dalam ritual juga dapat dijadikan bahan pelajaran terhadap peserta didik betapa pentingnya kerja sama dalam mencapai tujuan bersama. Nilai terpenting dalam ritual Perang Topat adalah nilai toleransi. Terlebih lagi dalam menjaga persatuan dan kesatuan dalam perbedaan toleransi adalah hal yang paling utama untuk diperhatikan. Melalui nilai toleransi di dalam ritual Perang Topat peserta didik dapat belajar bagaimana menghormati dan menghargai orang lain yang berbeda kepercayaan. Hasil penelitian di atas sesuai dengan penelitian Hanif (2016) yang menyatakan bahwa di dalam budaya lokal terdapat nilai-nilai luhur yang dapat dijadikan sumber belajar. Kebudayaan lokal dalam kesenian Dongkrek yang dikaji mengandung nilai kerohanian, spiritual, moral, kepahlawanan, kepemimpinan, keadilan, kesejahteraan, dan estetika

Pada dasarnya nilai-nilai budaya ritual Perang Topat dapat dijadikan sumber pembelajaran dari beberapa tema di atas baik tema 1 "indahnya kebersamaan", tema 7 "indahnya keragaman di Negeriku" dan tema 8 "daerah tempat tinggalku" di kelas IV maupun tema 2 "persatuan dalam perbedaan" di kelas VI . Namun dari beberapa tema tersebut yang paling erat hubungannya dengan nilai budaya ritual Perang Topat adalah tema 7 "indahnya keragaman di Ngeriku". Tema tersebut berkaitan erat dengan aspek budaya sehingga ritual Perang Topat dapat digunakan sebagai sumber belajar langsung pada pembelajaran IPS di kelas IV.

\section{Simpulan}

Berdasarkan hasil pembahasan dapat disimpulkan bahwa: 1) nilai budaya yang terkandung dalam ritual Perang Topat antara lain nilai kompromi, nilai religius, nilai historis, nilai kebersamaan dan persamaan derajat, nilai gotong royong, nilai musyawarah dan kekeluargaan, serta nilai toleransi, 2) nilai budaya pada ritual Perang Topat memiliki relevansi dengan KI/KD dan tema pembelajaran IPS di sekolah dasar di kelas IV dan kelas VI, 3) topik pembelajaran yang relevan dengan nilai budaya ritual Perang Topat antara lain tema 1 "indahnya kebersamaan", tema 7 "indahnya keragaman di Negeriku" dan tema 8 "daerah tempat tinggalku" yang terdapat di kelas IV serta tema 2 "persatuan dalam perbedaan" di kelas VI. Diantara beberapa tema di atas yang berkaitan paling erat adalah tema 7 di kelas IV "indahnya keragaman di Negeriku" karena berkaitan langsung dengan aspek keragaman budaya. 


\section{Daftar Pustaka}

Acim, S. A., \& Yaqinah, S. N. (2019). Nilai Kearifan Lokal pada Implementasi Komunikasi Antarbudaya dalam Tradisi Perang Topat di Lingsar, Lombok Barat. Lentera, 3(2), 95116.

Bahri, S. (2018). The Comparative Study On Sasak and Samawa Folktales: Understanding The People Of Sasak and Samawa. MABASAN, 12(2), 167-184.

Bakker SJ, J. W. M. (1984). Filsafat Kebudayaan: Sebuah Pengantar. Kanisius.

Gunawan, R. (2016). Pendidikan IPS: Filosofi, Konsep dan Aplikasi (3rd ed.). Alfabeta.

Hanif, M. (2016). KESENIAN DONGKREK (STUDI NILAI BUDAYA DAN POTENSINYA SEBAGAI SUMBER PENDIDIKAN KARAKTER). Gulawentah:Jurnal Studi Sosial, 1(2), 132-141. https://doi.org/10.25273/gulawentah.v1i2.1036

Jayadi, S., Demartono, A., \& Kartono, D. T. (2017). Interaksi Sosial Umat Hindu dan Muslim dalam Upacara Keagamaan dan Tradisi Perang Topat di Lombok. Jurnal Analisa Sosiologi, 6(2), 54-63.

Kusumawati, H. (2017). Indahnya Keragaman di Negeriku (M. Khairiyah, Rahmat, A. R. Wulan, P. Rahmawaty, B. Prihadi, W. Pekerti, \& Suharji. (eds.); 4th ed.). Kementerian Pendidikan dan Kebudayaan.

Larasati, D. (2019). Dampak Pembangunan Srambang Park Ngawi Terhadap Kehidupan Ekonomi Masyarakat Dan Potensinya Sebagai Sumber Materi Pembelajaran IPS SD. Gulawentah:Jurnal Studi Sosial, 4(1), 13. https://doi.org/10.25273/gulawentah.v4i1.4864

Marjan, \& Hariati, S. (2018). Tradisi Perang Topat Sebagai Akulturasi Agama dan Budaya (Masyarakat Desa Lingsar, Kecamatan Lingsar, Lombok Barat). Jatiswara, 33(1), 1-8. https://doi.org/https://doi.org/10.29303/jatiswara.v33i1.157

Peraturan Menteri Pendidikan Dan Kebudayaan Republik Indonesia Nomor 37 Tahun 2018, mendikbud 534 (2018).

Mintosih, S., Lestarining, A. D., \& Herliswani. (1999). Pengkajian Nilai Budaya Naskah Babad Lombok Jilid 1. Direktorat Jenderal Kebudayaan.

Moleong, L. J. (2009). Metodologi Penelitian Kualitatif (26th ed.). Remaja Rosdakarya.

Paramita, E. P., \& Suadnya, I. W. (2018). Analisis Kritis Penyebab Konflik Dalam Kelompok Masyarakat Kota Mataram Ditinjau Dari Perspektif Komunikasi. Media Bina Ilmiah, 12(9), 331-336.

Prastowo, andi. (2015). Panduan Kreatif Membuat Bahan Ajar Inovatif Menciptakan Metode Pembelajaran yang Menarik dan Menyenangkan. Diva Press.

Rosyadi, Mintosih, S., \& Soeloso. (1995). Nilai-nilai Budaya dalam Naskah Kaba Anggun Nan Tungga Si Magek Jabang Episode: Ke Balai Nan Kodo Baha. Direktorat Jenderal Kebudayaan.

Ruslan, S. (2019). Rekonstruksi Rumah Majapahit di Desa Bejijong Sebagai Sarana Edukasi Pendidikan IPS. Gulawentah:Jurnal Studi Sosial, 4(1), 56. https://doi.org/10.25273/gulawentah.v4i1.5033

Sapriya. (2017). Pendidikan IPS: Konsep dan Pembelajaran (8th ed.). PT Remaja Rosda Karya.

Sarpin, \& Pramunarti, A. (2017). Upaya masyarakat dalam melestarikan tradisi Perang Topat sebagai simbol persaudaraan umat Islam dan Hindu di desa Lingsar kecamatan Lingsar 
kabupaten Lombok Barat. Historis, 2(2), 24-28.

Suadnya, I. W., \& Paramita, E. P. (2018). Ritual Perang Topat Sebagai Strategi Komunikasi Dalam Menjaga Kebhinekaan : Lessons Learnt dari Tradisi Suku Sasak dan Bali Di Pulau Lombok. JCommsci - Journal of Media and Communication Science, 1(1). https://doi.org/10.29303/jcommsci.v1i1.6

Sugiyono. (2008). Metode penelitian kuantitatif kualitatif dan R\&D. Alfa Beta.

Suprapto. (2017). Sasak muslims and interreligious harmony: Ethnographic study of the perang topat festival in Lombok - Indonesia. Journal of Indonesian Islam, 11(1), 77-98. https://doi.org/10.15642/JIIS.2017.11.1.77-98

Susanto, A. (2014). Pengembangan Pembelajaran IPS di Sekolah Dasar (1st ed.). Prenadamedia Group.

Sutrisno, M., \& Putranto, H. (2005). Teori-Teori Kebudayaan. Kanisius.

Team Berugaq Institute. (2015). SASAK; Siapa, Bagaimana, dan Mau Ke Mana? (I. M. Salimudin \& M. S (eds.); Issue April). Berugaq Press.

Tumini, T. (2019). Peningkatan Motivasi dan Prestasi Belajar dengan Multimedia pada Pembelajaran IPS di Sekolah Dasar. Gulawentah:Jurnal Studi Sosial, 4(2), 93. https://doi.org/10.25273/gulawentah.v4i2.5556

Widodo, A., Akbar, S., \& Sujito, S. (2017). Analisis nilai-nilai falsafah Jawa dalam buku pitutur luhur budaya Jawa karya Gunawan Sumodiningrat sebagai sumber belajar pada pembelajaran IPS. Jurnal Penelitian Dan Pendidikan IPS (JPPI), 11(2), 152-179.

Widodo, A., Husniati, H., Indraswati, D., Rahmatih, A. N., \& Novitasari, S. (2020). Prestasi belajar mahasiswa PGSD pada mata kuliah pengantar pendidikan ditinjau dari segi minat baca. Jurnal Bidang Pendidikan Dasar, 4(1), 26-36. https://doi.org/https://doi.org/10.21067/jbpd.v4i1.3808

Widodo, A., Indraswati, D., Radiusman, R., Umar, U., \& Nursaptini, N. (2019). Analisis Konten HOTS dalam Buku Siswa Kelas V Tema 6 " Panas dan Perpindahannya " Kurikulum 2013. Madrasah: Jurnal Pendidikan Dan Pembelajaran Dasar, 12(1), 1-13. https://doi.org/http://dx.doi.org/10.18860/mad.v12i1.7744

Widodo, A., Indraswati, D., \& Sobri, M. (2019). Analisis Nilai-Nilai Kecakapan Abad 21 dalam Buku Siswa SD/MI Kelas V Sub Tema 1 Manusia dan Lingkungan. Tarbiyah: Jurnal Ilmiah Kependidikan, 8(2), 125. https://doi.org/10.18592/tarbiyah.v8i2.3231

Wirata I, W. (2015). Inter-cultural Communication between Local Hindu and Islamic Community in Perang Topat Ceremony in Lingsar Temple, Narmada District, Lombok. Indan Journal of Arts, 5(13), 7-10.

Wiwik Pertiwi, Hartati, Pananrangi Hamid, A. (1998). Kajian Nilai Budaya Naskah Kuna Mapalina Sawerigading Ri Saliweng Langi. Direktorat Jenderal Kebudayaan.

Yasa, I. M. A. (2020). Upacara Perang Topatdi Pura Lingsar Kecamatan Lingsar Kabupaten Lombok Barat. Media Bina Ilmiah, 14(9), 3179-3190. 